\title{
The National Spina Bifida Program
} Ann Alriksson-Schmidt, Mark Swanson and Judy Thibadeau*

Address: Centers for Disease Control and Prevention, National Center on Birth Defects and Developmental Disabilities, Division of Human Development and Disability, Mai-Stop E88, 1600 Clifton Road, Atlanta, GA 30333, USA

Email: Judy Thibadeau* - jthibadeau@cdc.gov

* Corresponding author

from 52nd Annual Meeting of the Society for Research into Hydrocephalus and Spina Bifida Providence, RI, USA. I I-I 4 June 2008

Published: 3 February 2009

Cerebrospinal Fluid Research 2009, 6(SuppI I):S49 doi:I0.II86/1743-8454-6-SI-S49

This abstract is available from: http://www.cerebrospinalfluidresearch.com/content/6/SI/S49

(C) 2009 Alriksson-Schmidt et al; licensee BioMed Central Ltd.

\section{Background}

Spina bifida affects approximately 1,200 of the more than 4 million babies born in the United States each year. Because of the increased mortality and long-term disability, the myriad of secondary conditions as well as the profound influence on affected individuals and their families, public health plays an essential role for individuals with spina bifida in terms of health promotion, prevention of secondary health conditions, and access to preventive health care, in addition to its role in primary prevention.

\section{Materials and methods}

A Secondary Conditions Symposium held in 1993, a conference, Evidenced Based Practice in Spina Bifida: Developing a Research Agenda held in 2004, and a Spina Bifida Clinic Survey conducted in 2005 revealed:

1) Lack of evidence-based care

2) Challenged system of clinical care:

a) great variability in care across clinics

b) a need for coordination and sharing of info in order to improve care and create opportunities for research

Strategic partnerships were formed among agencies such as the CDC, NIH, the Agency for Healthcare Research \& Quality, the Association of University Centers on Disability, the Department of Education's National Institute for
Disability and Rehabilitation Research, and the Spina Bifida Association (SBA).

\section{Results}

The National Spina Bifida Program, housed within the Disability and Health Team, National Center on Birth Defects and Developmental Disabilities at the Centers for Disease Control and Prevention, was formed to coordinate spina bifida-related research efforts and programs, with the goal of improving the health and wellness and thus life participation of persons with spina bifida. This poster will detail the National Spina Bifida Program to include: Assessment and Evaluation of the Role of Care Coordination in Improving Access and Care within the Spina Bifida Clinic System; Bowel and Bladder Continence effectiveness projects; National History of Spina Bifida in Children longitudinal study pilot; Secondary Conditions and Related Factors; Transition across the Lifespan; Analysis of Veterans' Administration Healthcare Program for Spina Bifida; development of a Spina Bifida Clinical Care Network; development of a Spina Bifida Patient Registry; development of a Spina Bifida Electronic Medical Record; and National Spina Bifida Initiatives: Prevalence, Resources and Quality of life.

\section{Conclusion}

The Spina Bifida Association and CDC have partnered to reduce health disparities and improve the quality of care for persons with spina bifida, to use clinical settings to collect information for research, to assess transition at developmental stages across the life span, and to create a 
prospective study on the natural history of spina bifida. The collaboration between clinics and agencies is critical to better understand the needs of the population and take the necessary steps to improve quality of life. This poster will outline the National Spina Bifida program as a model which could be replicated with other conditions of childhood which result in life long challenges to health, quality of life and participation.

Publish with Bio Med Central and every scientist can read your work free of charge

"BioMed Central will be the most significant development for disseminating the results of biomedical research in our lifetime. " Sir Paul Nurse, Cancer Research UK

Your research papers will be:

- available free of charge to the entire biomedical community

- peer reviewed and published immediately upon acceptance

- cited in PubMed and archived on PubMed Central

- yours - you keep the copyright

Submit your manuscript here:

http://www.biomedcentral.com/info/publishing_adv.asp 